\title{
ПРЕДИКАТИВНІ ПРИКМЕТНИКИ ЯК СКЛАДНИКИ МОВЛЕННСВОГО АКТУ ВИБАЧЕННЯ
}

\author{
Дейчаківська О. В.
}

\section{ВСТУП}

Структуралізм, метою якого був опис мови як певної логічної, а водночас абстрактної схеми супроводжувався і послабленням інтересу до галузі, в якій проявляються мовленнєві дані, тобто до мовленнєвої діяльності. Саме тому виникла необхідність спрямувати конструктивно орієнтований синтаксис до того, що є «соціальним призначенням мови, а саме до використання речень у мовленнєвій діяльності» ${ }^{1}$.

Мовленнєві акти класифікуються з різних точок зору: відповідно до типу ілокутивної сили та способів її досягнення; відповідно до статусу мовця і слухача. У центрі уваги дослідників було також вивчення окремих мовленнєвих актів. А проте спроби аналізу власне засобів, за допомогою яких знаходили вираження ті чи інші мовленнєві акти, не проводилися і вивчення структур з позицій їхнього функціонування як центральних чи близьких до центральних засобів вираження того чи іншого мовленнєвого акту (такими можуть виступати предикативні прикметники в моделі Vcop+Adj) не робилося, тобто реверсний спосіб аналізу «від форми до понятійного наповнення» не здійснювався i належним чином не вивчався.

Прагматичний аспект предикативних прикметників не був предметом спеціального вивчення, тоді як проведений аналіз структурно-семантичних особливостей структури Vcop+Adj засвідчує, що коли у функції предикатива $є$ прикметники оцінки, то вся структура виражає експресивні мовленнєві акти. Найчастіше це мовленнєві акти вибачення, вдячності і висловлення компліменту.

Висока частотність саме цих мовленнєвих актів засвідчує, що нині в центрі уваги дуже часто перебувають саме ті мовленнєві дії, які інформують про психологічний стан мовця, його вміння висловлювати свої почуття і таким чином впливати на емоційний стан адресата. Окрім дієслів, які слугують засобами вираження цих мовленнєвих актів, поза увагою дослідників залишались предикативні прикметники

1 Иванова И.П., Бурлакова В.В., Почепцов Г.Г. Теоретическая грамматика современного английского языка. Москва : Высшая школа, 1981. С. 268. 
як компоненти структури Vcop+ Adj, які також є лексичними засобами вираження вибачення, подяки, висловлення компліменту.

Вищезазначені мовленнєві акти належать до групи експресивів відповідно до класифікації Дж. Серля² ${ }^{2}$ На думку Дж. Серля, ілокутивна мета експресивів полягає в тому, щоби виразити психологічний стан, викликаний почуттям щирості, стосовно ситуації, визначеної змістом пропозиції.

Цікавим $\epsilon$ спостереження Е. Блек ${ }^{3}$ щодо змісту експресивів у контексті різних типів дискурсу. «Експресивні акти - це такі мовленнєві акти, які виявляють позицію мовця у ситуаціях вітання, висловлення співчуття чи вираження задоволення. Вони виконують дуже сильну міжособистісну функцію. Ось чому в художній літературі 3 більшою ймовірністю на них можна натрапити в персонажному дискурсі, аніж у наративі» - лінійному викладі фактів і подій у літературному творі.

\section{1. Загальна характеристика мовленнсвого акту вибачення. Поліінтенційність акту вибачення, вираженого структурою Vcop+Adj}

Окрім визнання мовцем негативного ставлення до вчиненої дії, суть мовленнєвого акту вибачення полягає у бажанні заслужити пробачення, а також часто супроводжується спробою виправдати свою поведінку 3 метою відновлення втраченої рівноваги у стосунках зі співрозмовником. Мовець намагається досягти порозуміння 3 тими, кого він образив. Мовленнєвий акт вибачення $є$ компенсаторним, типовим ретроспективним актом, який стосується вчиненого в минулому порушення соціальних домовленостей ${ }^{4}$. Гофман називає мовленнєвий акт «діяльністю, скерованою на виправлення ситуації, оскільки його метою $є$ відновлення соціальної гармонії за ймовірну чи дійсну образу або ж заподіяну шкоду» 5 .

У рамках теорії ввічливості П. Браун та С. Левінсона, основу якої становить поняття «обличчя» ${ }^{6}$ - позитивного і негативного - а також

${ }^{2}$ Searle J. The Classification of Illocutionary Acts. Language in Society. Cambridge : Cambridge University Press. 1976. Vol. 5. P. 1-24.

${ }^{3}$ Black E. Pragmatic Linguistics. Edinburg : Edinburg University Press. 2006. P. 7.

${ }^{4}$ Bergman M., Kasper G. Perception and Performance in Native and Non-native Apology. Interlanguage Pragmatics. New York : Oxford University Press. 1993. P. 82-107.

${ }^{5}$ Goffman E. Interaction Ritual: Essays on Face-to-Face Behavior. Garden City, New York : Anchor @Doubleday. 1967.270 p.

6 «Позитивне» обличчя людини асоціюється 3 іï бажанням бути тим, хто користується повагою в суспільстві, чиї вчинки заслуговують схвалення та викликають симпатію, тоді як «негативне» - прагнення користуватися свободою у своїх вчинках (див. Brown 1987, 129). Обличчя завжди перебуває в центрі уваги комунікантів у процесі інтеракції (див. Brown, Levinson 1978, p. 66). 
поняття позитивної і негативної ввічливості, висловлювання, що вживаються для вираження вибачення належать до стратегій негативної ввічливості. Мовець, беручи на себе провину за скоєний негативний вчинок, висловлює свою повагу до адресата та виражає своє прагнення звільнитись від почуття провини. Визнаючи свою відповідальність за здійснену негативну дію, адресант ставить себе у вразливе становище, чим загрожує своєму обличчю. При цьому позитивна ввічливість полягає у виявленні зацікавленості до дій та особистості партнера, у вираженні схвалення ${ }^{7}$, натомість негативна ввічливість має на меті уникнення та пом'якшення тих мовленнєвих актів, які могли б загрожувати обличчю людини, скажімо наказів, критичних зауважень чи прямих прохань на адресу співрозмовника.

Думку про те, що мовленнєвий акт вибачення розглядається як такий, що «руйнує» обличчя мовця і «зміцнює» обличчя адресата не зовсім поділяє Р. Ратмайр ${ }^{8}$, зазначаючи, що вибачення за незначну провину не лише сприяє позитивному іміджу адресата, але й адресанта, оскільки мовець, вибачаючись за незначну провину, декларує себе ввічливою людиною. Однак якщо все ж існує вагомий привід для вибачення, то мовець все-таки применшує свій авторитет, визнаючи свою вину, і піднімає авторитет партнера по комунікації (надаючи йому в цей момент можливість вирішувати долю їхніх подальших стосунків).

За Дж. Серлем ${ }^{9}$, вибачення є стандартним прикладом експресивних мовленнєвих актів, ілокутивна мета яких полягає в тому, щоб «висловити, названий в умовах щирості стан мовця, який пов'язаний зі станом справ, зазначених у пропозиції». На те, що для мовленнєвого акту вибачення характерними є також почуття жалю та каяття, вказує Н. Норрік ${ }^{10}$. Соціальна функція вибачення полягає у тому, що мовець бере на себе відповідальність за настання несприятливого стану справ, тому вибачення завжди супроводжується станом каяття.

Вибачення є поліінтенційним типом мовленнєвої діяльності, тобто стереотипні стратегї вибачення можна поділити на низку різновидностей залежно від реалізації ними додаткових інтенцій, де поряд із поняттями вибачення виражено також пояснення, що призвело до вчинення небажаної дії; визнання відповідальності за скоєне; прохання; обіцянку не вчиняти подібних дій у майбутньому;

7 Brown P., Levinson S. Some Universals in Language Usage. Cambridge : Cambridge University Press. 1978. P. 75.

${ }^{8}$ Ратмайр Р. Прагматика извинения. Москва : Языки славянской культуры. 2003. C. $22-23$.

${ }^{9}$ Searle J. Ausdruck und Bedeutung. Frankfurt a. M.: Suhrkamp. 1982. S. 34 P. 284.

${ }^{10}$ Norrick N. Expressive Illocutionary Acts. Journal of Pragmatics. Vol. 2(3). 1978. 
запевнення в небажанні вчиняти малефактивну дію, пропозицію стосовно відшкодування заподіяної шкоди. Оскільки в такому разі йдеться про вибачення, виражене предикативними прикметниками, то найчастіше натрапляємо на випадки, коли, вибачаючись, мовець визнає факт вчинення дії, яка:

a) якимось чином образила слухача (визнання відповідальності):

- I'm sorry I was so beastly to you just now ${ }^{11}$ - адресат перепрошує за свою не зовсім відповідну поведінку;

б) надає пояснення, що саме призвело до вчинку, який вніс дисбаланс у стосунки:

- It was getting so late, I was afraid you weren't coming.

- I'm sorry, some tiresome people came around after the play and I couldn't get rid of them ${ }^{12}$;

в) шкодує за необхідністю вчинити малефактивну дію, однак наголошує на неможливості уникнути ситуації, що приведе до порушення рівноваги у стосунках між комунікантами:

- I am sorry to disappoint you, my friends, but it is clear to me from this manuscript, which I had not examined in many years, that a group of pilgrims traveled back to Wallachia from Sveti Georgi about $1478^{13}$. Одержана інформація $є$ неочікуваною для слухачів і певною мірою зачіпає їхню професійну компетентність, тому вибачення з боку мовця аж ніяк не $є$ зайвим. Однак подальша розповідь адресанта про те, наскільки корисною може виявитися ця інформація, лише підкреслює вимушеність малефактивної дії та, відповідно, необхідність вибачення, яке слідує далі.

Ті ж стратегії вибачення спостерігаємо, коли мовленнєвий акт вибачення виражається за допомогою синонімічної фрази із предикативним прикметником afraid.

Найчастіше воно вживається, коли слухач, до якого звертається мовець, не здогадується про те, за що проситимуть пробачення, а тому відразу ж за вибаченням слідує пояснення. - I'm afraid I shall have to go in a minute, she said. - I'm late already ${ }^{14}$. Мовець повідомляє $\mathrm{i}$ водночас просить вибачення за те, що має намір покинути співрозмовника, оскільки вже спізнюється.

Натрапляємо i на випадки, коли предикативний прикметник "afraid" вказує на вибачення за здійснену малефактивну дію, за порушення певних соціальних домовленостей.

${ }^{11}$ Maugham S. Theatre. Moscow : Vyssaja Skola. 1985. P. 154.

${ }^{12}$ Theatre... P. 87.

13 Kostova E. The Historian. New York, Boston, London : Little, Brown and Company. 2005. P. 729.

${ }^{14}$ Theatre... P. 176. 
- This is an unusual party for me. I haven't even seen the host. I live over there - ... and this man Gatsby sent over his chauffeur with an invitation. For a moment he looked at me as if he failed to understand. - I'm Gatsby, he said suddenly. - What! I exclaimed. - Oh, I beg your pardon. I thought you knew, old sport. I'm afraid I'm not a very good host ${ }^{15}$. Співрозмовник, в якого будуть просити пробачення, довго пояснює, наскільки дивною $€$ вечірка, оскільки він ніяк не може знайти господаря. Господар, котрий уже якийсь час раніше розмовляв із гостем і при цьому аж ніяк не припускав, що його не впізнали, просить пробачення за свою неуважність і за спричинені незручності.

\section{2. Мовна реалізація мовленнєвого акту вибачення у разі вибору структури Vcop+Adj}

Найчастотнішим засобом вираження прямого мовленнєвого акту вибачення в англійській мові є прості (повні та еліптичні) речення, що містять прикметник "sorry". Відразу ж варто зауважити, що сам лише прикметник "sorry" вживається або у разі дуже незначної провини або ж у розмові 3 незнайомими людьми. Нижченаведені приклади ілюструють саме такі ситуації.

- Sorry to steal in like this. Your gate out there's locked.

She shook her head. Just pull on it. The padlock. I'm sorry ${ }^{16}$.

У такій ситуації гість коротко вибачається за те, що «прокрався» на подвір'я, оскільки ворота були зачинені. Слухач пояснює, що насправді ворота не були замкнені на ключ - досить було лише потягнути за замок, але, своєю чергою, теж просить вибачення за незручну ситуацію, у яку попав мовець. У підсумку баланс соціальних стосунків $\epsilon$ досягнутим. Але саме тому, що негативний вчинок є незначним, а сама розмова відбувається між незнайомими людьми, які вперше бачать одне одного, обидва учасники комунікативної ситуації обмежуються словами "sorry" 3 опущеним підметом та частиною присудка у висловлюванні адресанта (першій фразі) та простим непоширеним реченням 3 прикметником "sorry" у відповіді слухача у другій фразі наведеного мінідіалогу.

Аналогічна форма вибачення - непоширене речення “I'm sorry", як і його синонім у заперечній формі "I'm afraid not" - звучить і у разі розмови між малознайомими людьми, коли за наполяганням одного зі співрозмовників визнати своє знайомство 3 певною людиною адресат відповідає відмовою. Проте при цьому адресат просить мовця вибачити

\footnotetext{
${ }^{15}$ Fitzgerald F. The Great Gatsby. Kyiv : Znannia. 2013. P. 53.

${ }^{16}$ Fowles J. The Ebony Tower. Eliduc. The Enigma. Moscow : Progress Publishers. 1980. P. 36.
} 
його, усвідомлюючи, що його відмова $\epsilon$ малефактивною дією i відсутність вибачення може призвести до дисгармонії стосунків, тоді як вибачення буде шляхом до примирення.

- Mr. Pine, do you know Richard Roper?

- I'm afraid not.

- But you must. He is famous. He is beautiful. ...Mr. Richard Onslow Roper? One of your famous international entrepreneurs. Come.

- Not a name to me. I'm sorry ${ }^{17}$.

Варто звернути увагу i на подвійне вибачення у наведеному прикладі, оскільки, хоч розмова і відбувається між людьми, чиє знайомство щойно розпочалось, така форма вибачення говорить про щире бажання заслужити пробачення. I хоча, на думку деяких дослідників, стисле вибачення у формі простого непоширеного речення наближається до етикетного, оскільки воно не демонструє відчуття i визнання провини, такі синтаксичні засоби, як повтор та різноманітні інтенсифікатори, які будуть проаналізовані далі, все ж говорять на користь фактору щирості, який $є$ в центрі всіх висловлювань, що конструюють певну ситуацію. При цьому формули вибачення використовуються не як етикетні знаки, а як засіб вираження емоційного стану комунікантів.

Отже, коли мовець щиро визнає свою провину, в реченнях дуже часто трапляються різноманітні інтенсифікатори - so, very, terribly, awfully, які, відповідно, підсилюють дію цього акту. Власне, саме ці інтенсифікатори і засвідчують усвідомлення мовцем своєї вини i бажання гармонізувати стосунки. Характерним для англійської мови, а особливо для іiї американського варіанта $\epsilon$ те, що чим ближчі стосунки між співрозмовниками, тим необхіднішим $\epsilon$ вживання інтенсифікатора. У протилежному випадку вибачення не буде вважатися щирим, i одержання бажаного результату через мовленнєвий вплив на адресата, а саме очікуване пробачення не буде досягнутим.

- You're not to leave me now! I must talk to somebody. I thought we might go and have a snack together before the show.

- I'm terribly sorry. Jimmie's expecting me and you know what he is ${ }^{18}$.

Розмова відбувається між нареченими і для того, щоби бажання нареченої залишити на якийсь час свого супутника не виглядало неввічливим, звертаючись до нього, вона вживає інтенсифікатор "terribly".

Той же ж інтенсифікатор вживається і у разі, коли близька знайома звертається до хлопчика 3 проханням залишити іiі, 3 огляду на

${ }^{17}$ Le Carre J. The Night Manager. Penguin Books Canada Ltd. 1993. P. 12.

${ }^{18}$ Theatre... P. 40. 
необхідність вирішити низку нагальних і важливих справ. Ці справи стосуються дорослих людей, але через те, що 3 хлопцем жінку пов'язують приязні стосунки, що більше, вона зобов'язана йому, у звертанні жінка також вживає слово “terribly” перед прикметником "sorry", як і синонімічний вираз "I'm afraid", що засвідчує як близькість їхніх стосунків, так і щирість іiї вибачення за спричинені незручності.

- I'm terribly sorry, but I'm afraid we have some grown-up business to attend to. We're to meet with the lawyer shortly. As soon as Pippa's nurse arrives $^{19}$.

Ще один приклад містить не так часто вживаний інтенсифікатор “unspeakably", який, безперечно, засвідчує високий ступінь провини мовця, його розуміння своєї провини $\mathrm{i}$ намагання заслужити пробачення.

- My dear man. So unspeakably sorry about last night. Gels tell me most appallingly rude ${ }^{20}$.

За виразом "I'm sorry" може слідувати прийменник "for", підрядне особове речення або інфінітив. Особові речення, які слідують за виразом "I'm sorry" пояснюють або виправдовують дію мовця, що спричинила небажаний ефект, а також виражають обіцянку чи прохання.

- I'm sorry. Her dark face hadn't asked for pity but I felt it. - I wish I had some clues for you here but you see how it is. I can't explain it either.

- At least we believe each other ${ }^{21}$.

Наведений приклад ілюструє вибачення, за яким слідує пояснення. Водночас жінка констатує і той факт, що їй не вдалося досягти бажаної мети, однак пояснення тих причин, які перешкодили цьому, допомагають їй як адресанту сформулювати позитивну думку про себе. На рівні синтаксису пояснення виражено умовним реченням, яке слідує за фразою “I'm sorry". У результаті між співрозмовниками досягнуто порозуміння. Перлокутивний ефект - одержання пробачення досягнуто, про що свідчить фраза-відповідь співрозмовника. Здебільшого якраз пояснення, яке слідує за фразою “I'm sorry", допомагає адресанту трансформувати негативну думку про себе у позитивну: - Sorry we are so late, said Roger. There was a filthy crowd and we had to wait on nearly every tee. We halfed a match ${ }^{22}$.

\footnotetext{
${ }^{19}$ The Goldfinch... P. 154.

${ }^{20}$ The Ebony Tower... P. 75.

${ }^{21}$ The Historian... P. 202.

${ }^{22}$ Theatre... P. 96.
} 
Обидві ситуації ілюструють пояснення стосовно того, що заставило мовця здійснити малефактивну дію (у другому прикладі воно виражене за допомогою підрядного речення із пропущеним сполучником "that"), яке слідує за вибаченням. Мета пояснення - трансформувати обличчя мовця, пом'якшити негативний ефект.

Натомість у разі вживання інфінітива вказується на небажання адресантом виконати дію, яка так чи інакше створила дисгармонію у стосунках між комунікантами, а однак уникнути якої було неможливо. - I have used every channel I could think of, including some I am sorry to say - that I cannot tell you about ${ }^{23}$.

Повні та еліптичні речення, що містять прикметник "sorry" становлять найчисленнішу групу, за допомогою яких виражаються мовленнєві акти вибачення в англійській мові ${ }^{24}$. 3 цим фактом погоджуються багато дослідників i деякими 3 них ця фраза визначається як немаркована, а отже, і рутинна ${ }^{25}$. Проте, як цілком слушно зауважує Н. Норік ${ }^{26}$, незначна інтенсивність почуттів, властива етикетним актам, не $\epsilon$ показником «емоційного збіднення» сучасного суспільства. Емоційне навантаження на людину було б надто великим, якби вона співчувала своїм партнерам по комунікації тією мірою, в якій вона сама це відчуває.

Фраза "I'm sorry" вживається із різними займенниками у функції підмета та різними часовими формами присудка.

... it might be that he would be sorry ... . If he did that she would forgive him everything ${ }^{27}$. У цьому прикладі натрапляємо на займенник третьої особи однини у функції підмета, хоча найчастіше у цій функції вживається прийменник першої особи однини.

Наступний приклад ілюструє еліптичне речення із предикативним прикметником "sorry", при цьому пропущеними є підмет (у формі прийменника першої особи однини) та дієслово-зв'язка «бути». Sorry. If I'm sounding all-wise. But I do know him ${ }^{28}$.

У випадку, коли за прикметником "sorry" слідує підрядне речення, у функції підмета зазвичай натрапляємо на займенник першої особи однини у функції підмета.

${ }^{23}$ Historian... P. 598.

24 Чередніченко О.М. Мовні засоби вираження вибачення. Наукові записки Начіонального університету «Острозька академія». Серія : Філологічна. 2016. Вип. 62. С. 343-345.

${ }^{25}$ Perception and Performance in .... P. $64-81$.

${ }^{26}$ Expressive Illocutionary Acts ... P. 287.

27 Theatre... P.108.

${ }^{28}$ Fowles... P. 60. 
-I'm sorry that my wife is out - she teaches at the nursery school ${ }^{29}$.

Заслуговують на увагу приклади вживання прикметника "sorry" у наративі, хоча вони і не $\epsilon$ високочастотними. Як правило, в таких випадках за вибаченням одразу ж слідує пояснення, підмет вживається в третій особі однини, а присудок у минулому часі. Порівняння випадків, коли у художніх творах за персонажним мовленням одразу ж слідує наратив і в обох випадках як у персонажному, так і в мові автора вжито формули вибачення 3 предикативним прикметником "sorry", підтверджує спостережену різницю у граматичному оформленні способів вибачення.

- Perhaps if he has a splendid motor-yacht he doesn't have to bother with hotels. I don't read the newspapers enough. I'm out of touch. I'm sorry.

- But madam Sophie was not sorry ${ }^{30}$.

Адресат вибачається за те, що не може надати необхідної інформації, тоді як мовець, як це засвідчує наратив, аж ніяк не шкодує за ситуацією, що склалася.

У наступному прикладі внаслідок несподівано перерваної розмови, як $\mathrm{i}$ самого предмета обговорення, який був важким для співрозмовників, одному 3 комунікантів доводиться попрощатися. Мова автора засвідчує, з яким небажанням він це робить.

- In his haste, Burr failed to notice his cigarette burning in Quasely's ashtray. Jonathan stubbed it out, sorry to be saying good bye $e^{31}$.

У розмові, яка відбулась між старшою людиною, що запропонувала приготувати їжу, відмова хлопчика прозвучала настільки грубо i неввічливо, що сам мовець відчув це і відразу ж вибачився:

- "I'm not hungry", I said so rudely I was sorry ${ }^{32}$.

Саме у разі вживання вибачення у наративі, а не у персонажному дискурсі, ми переважно натрапляємо на підмет у третій особі однини та форму минулого часу присудка. У разі ж персонажного дискурсу підмет зазвичай вживається у формі займенника першої особи однини, а присудок у теперішньому часі.

\section{3. Реалізація непрямих актів вибачення}

Особливий інтерес являють випадки непрямого вибачення, коли воно виражається за допомогою інших ілокуційних актів. Ключем до розуміння вибачення слугує контекст.

\footnotetext{
${ }^{29}$ Historian... P. 320.

${ }^{30}$ The Night Manager... P. 13.

${ }^{31}$ Ibid. P. 62.

32 The Goldfinch... P. 131.
} 
Про непрямі мовленнєві акти йдеться, коли один мовленнєвий акт вживається замість іншого і саме на розсуд мовця залишається вияснити, яким $\epsilon$ намір адресанта. Досвід слухача повинен допомогти йому відповідно проінтерпретувати непрямий акт. Мовець експліцитно виражає один зміст, при цьому імпліцитно закладаючи у власне висловлювання інший. Непрямими актами вибачення вважаємо такі, ілокуцію яких виражено за допомогою форм, характерних для інших мовленнєвих актів, наприклад обіцянки, пропозиції, прохання, пояснення.

Тут варто зазначити, що у мовленнєвому акті розмежовують семантичний та прагматичний аспекти. Семантику мовленнєвого акту формують безпосередньо лексичні одиниці. Натомість прагматика мовленнєвого акту - це кінцева мета повідомлення, це той результат, якого мовець прагне досягнути, коли продукує висловлювання ${ }^{33}$. Тобто значення мовленнєвого акту не зводиться до значення його пропозиції, оскільки одна і та ж пропозиція залежно від контексту може слугувати засобом вираження різних мовленнєвих актів.

Якщо семантичний та прагматичний аспекти збігаються, то йдеться про прямий мовленнєвий акт. Усі вищенаведені приклади ілюстрували прямий мовленнєвий акт вибачення.

Якщо ж семантичний і прагматичний компоненти не збігаються, i тільки контекст допомагає зрозуміти, якій ілокутивній інтенції слугують ті чи інші лексичні засоби, то йдеться про непрямий мовленнєвий акт.

Емпіричні дані засвідчують такі випадки непрямого вибачення:

a) вибачення шляхом пояснення:

- I'm so lonely and your friendship meant a great deal to $\mathrm{me}^{34}$;

b) вибачення шляхом обіцянки:

... if you are still angry with me, we'll call it a day $y^{35}$;

Закономірно, що у разі, коли непрямий акт вибачення реалізується у формі обіцянки, присудок вживається у майбутньому часі.

в) пояснення та інформування:

- I never allow outsiders to come to rehearsals, but as you're our accountant you almost belong to the theatre...

- That would be terribly kind of you I've never been to a rehearsal in my life. Are you going to act in the next play?

33 Селіванова О.О. Основи теорії мовної комунікації. Черкаси : Вид-во Чабаненко Ю.А. 2011. 350 с.

${ }^{34}$ Theatre... P. 113.

${ }^{35}$ Theatre... P. 110. 
- Oh, I don't think so. I'm not keen about acting any more. I find it almost impossible to find a part to suit me.

Новоприбулий бухгалтер одержує дозвіл бути присутнім на репетиціях, що зазвичай забороняється всім працівникам театру, за винятком акторів. Знаючи, що директор також актор, клерк запитує, чи й він гратиме у виставі. Випереджаючи можливе розчарування i водночас перепрошуючи за нього, директор інформує бухгалтера i водночас пояснює йому, що він уже давно не є настільки зацікавлений грою на сцені, як це було раніше, оскільки йому важко підшукати для себе відповідну роль ${ }^{36}$.

У всіх вищенаведених прикладах предикативні прикметники "lonely", “angry", “keen” (останній вжито у заперечній формі) функціонують як синоніми прикметника "sorry". Семантика жодного 3 них не має семи вибачення. Лише контекст вказує, що мовці шкодують за вчиненим і демонструє їхні спроби пояснити свою поведінку або ж обіцянку не робити чогось подібного в майбутньому.

Слід зазначити, що непрямі мовленнєві акти вибачення не $\epsilon$ високочастотними. Однією з причин виступає той факт, що у разі непрямого вибачення інтенція мовця не є однозначною і потребує ширшого контексту для уникнення двозначності.

Мовленнєвий акт вибачення виражений за допомогою предикативного прикметника "sorry" слід відрізняти від випадків, коли цей прикметник слугує засобом вираження співчуття, розуміння чи стурбованості з приводу проблем співрозмовника чи співрозмовників.

- You couldn't possibly have slept in that carriage, he said. - There's a man there who's a heavy breather. I'd almost rather he snored. If he snored one could wake him.

I'm so sorry ${ }^{37}$.

У наведеному прикладі слухач не вибачається. Вислухавши скарги співрозмовника, адресат висловлює своє розуміння.

В іншому випадку в розмові між молодою жінкою та ії давнім знайомим прикметник "sorry" також не вжито для вираження вибачення.

- Are you sorry?, I asked.

- I'm neither pleased nor sorry. I just couldn't help myself ${ }^{38}$.

Співрозмовник питає молоду жінку, чи вона шкодує за вчиненим. Як слідує з її відповіді прикметник "sorry” вжито не для вибачення, а для пояснення своїх дій.

\footnotetext{
${ }^{36}$ Theatre... P. 17.

${ }^{37}$ Ibid. P. 82.

${ }^{38}$ Maugham S. The Razor'z Edge. London. Pan books. 1980. P. 98.
} 
Ще один приклад із предикативним прикметником "sorry" контекстуально засвідчує співчуття.

- Sorry you didn't win. That was for the golf tournament. She had lost in the finals the week before ${ }^{39}$.

Як витікає зі слів автора, хтось із присутніх висловлює співчуття відомій спортсменці з приводу програшу у фіналі. Засобом вираження співчуття слугує прикметник “sorry".

Саме про співчуття, а не вибачення йдеться і у разі, коли за прикметником "sorry" слідує прийменник "for": I thought he was sorry for $m e^{40}$.

\section{ВИСНОВКИ}

Аналіз мовленнєвого акту вибачення, вираженого моделлю Vcop+Adj, засвідчує його приналежність до класу експресивів мовленнєвих актів, що виражають розуміння, співчуття, вибачення i спрямовані на зміну психологічного стану адресата.

Варто зазначити, що поряд із різними типами речень, в яких вживаються прикметники "sorry" та "afraid", а це - прості та складнопідрядні речення, предикативні прикметники вживаються для вираження як прямих, так і непрямих мовленнєвих актів вибачення. На основі контексту виявлено, що непряме вибачення реалізується за допомогою форм, характерних для інших мовленнєвих актів: обіцянки, пояснення, повідомлення.

Емпіричні дані засвідчують низькочастотність вживання непрямого вибачення. Переважання прямого вибачення пояснюється чіткістю вираження бажання заслужити пробачення.

Вживання поряд із предикативними прикметниками різноманітних інтенсифікаторів, синонімічних структур, повторів дає змогу провести межу між фатичним та щирим вибаченням. Проаналізовані приклади засвідчують синкретичний характер предикативного прикметника "sorry", що спонукає адресата послуговуватись ширшим контекстом для визначення характеру ілокуції.

Тип дискурсу слугує поясненням дейктичного та часового оформлення компонентів структури із предикативним прикметником.

\section{АНОТАЦІЯ}

Визначено прагматичні особливості структури Vcop+ Adj як засобу вираження вибачення. Поряд із класифікацією Дж. Серля, така структура проаналізована в рамках «теорії ввічливості», за способами

${ }^{39}$ The Great Gatsby... P. 47.

${ }^{40}$ Spark M. The Public Image. Stories. Moscow : Progress Publishers. 1976. P. 122. 
мовного втілення та з точки зору фактору щирості. Функціонування такої структури в різних сферах комунікації дає змогу охарактеризувати ii як один зі способів вираження універсальних мовленнєвих актів, до яких належить і мовленнєвий акт вибачення.

На синтаксичному рівні за предикативним прикметником може слідувати прийменниковий зворот, підрядне речення або ж інфінітив. Тип структури визначає рівень близькості комунікантів.

3 точки зору позиції в дискурсі конструкція характеризується як засіб вираження ініціального акту, за яким слідує продовження i розвиток дискурсу. Можливі варіанти такого розгортання дискурсу, а саме згода чи відмова пробачити завдану образу або ж заподіяну шкоду, слугуватимуть предметом подальших досліджень.

\section{ЛІТЕРАТУРА}

1. Иванова И.П., Бурлакова В.В., Почепцов Г.Г. Теоретическая грамматика современного английского языка. Москва : Высшая школа. 1981. $235 \mathrm{c}$.

2. Ратмайр Р. Прагматика извинения. Москва : Языки славянской культуры. 2003.272 с.

3. Селіванова О.О. Основи теорії мовної комунікації. Черкаси : Вид-во Чабаненко Ю.А. 2011. 350 с.

4. Чередніченко О.М. Мовні засоби вираження вибачення. Наукові записки Начіонального університету «Острозька академія». Серія: Філологічна. 2016. Вип. 62. С. 343-345.

5. Bergman M., Kasper G. Perception and Performance in Native and Non-native Apology. Interlanguage pragmatics. New York : Oxford University Press. 1999. Pp. 82-107

6. Black E. Pragmatic Linguistics. Edinburg : Edinburg University Press. 2006. 167 p.

7. Brown P., Levinson S. Politeness: Some Universals in Language Usage. Cambridge : Cambridge University Press. 1978. 347 p.

8. Fitzgerald F. The Great Gatsby. Kyiv : Znannia. 2013.197 p.

9. Fowles J. The Ebony Tower. Eliduc. The Enigma. Moscow : Progress Publishers. 1980. 246 p.

10. Goffman E. Interaction Ritual : Essays on Face-to-Face Behavior. Garden City, New York : Anchor @ Doubleday. 1967.270 p.

11. Kostova E. The Historian. New York, Boston, London : Little, Brown and Company, $2005.909 \mathrm{p}$.

12. Le Carre J. The Night Manager. Penguin Book Canada Ltd. 1993. $429 \mathrm{p}$.

13. Maugham S. The Razor's Edge. London : Pan Books. 1980. 314 p.

14. Maugham S. Theatre. Moscow : Vyssaja Skola. 1985. 223 p. 
15. Norrick N. Expressive Illocutionary Acts. Journal of Pragmatics. Vol. 2 (3). 1978. Pp. 277-291.

16. Searle J. The Classification of Illocutionary Acts. Language and Society. Cambridge. Cambridge University Press. 1976. Vol. 5. Pp. 1-24.

17. Searle J. Ausdruck and Bedeutung. Frankfurt am Main : Suhrkamp. 1982. $211 \mathrm{~s}$.

18. Spark M. The Public Image. Stories. Moscow : Progress Publishers. 1976.292p.

19. Tartt D. The Goldfinch. New York. Back Bay Books / Little, Brown and Company, 2013, pp. 771.

\section{Information about the author:} Deychakivska O. V., Candidate of Philological Sciences, Associate Professor at the Department of English Philology

Ivan Franko National University of Lviv 1, Universytetska str., Lviv, 79000, Ukraine 